\title{
COMPORTAMENTO DE TECIDOS À IMPLANTAÇÃO DE PARTICULAS ESFÉRICAS DE LIMALHA
}

\section{SINOPSE}

Implantaram no dorso de camundongos partículas de limalha empregada na preparação de amálgama. Decorridos 12, 13, 14 e 15 meses sacrificam-se grupos de animais, estudando-se histològicamente a região de implante. Não são observadas alterações moriológicas significativas nos tecidos da região estudada.

O emprêgo crescente, nos U.S.A., e no Japão, de partículas esféricas na preparação de amálgama para uso em restaurações dentárias (1) tem motivado a publicação de numerosos trabalhos.

Normalmente o amálgama é ajustado a uma cavidade preparada na dentina. Algumas vêzes porém, ain-

\author{
Hardy Ebling \\ Professor Titular de Patologia Geral \\ e Bucodental do Departamento 2. \\ Edgar Mário Wagner \\ Professor da Faculdade de Medicina \\ da U.F.R.G.S.
}

da que acidentalmente, o amálgama pode ser introduzido no alvéolo dentário (3). Ẽ possível, porém, que ainda não se tenham feito observações suficientes sôbre as reações que ocorrem no organismo à presença de pequenas esferas dêste tipo junto a determinados tecidos, o que é motivo do presente trabalho.

\section{MATERIAL E MÊTODO}

Foram implantados, segundo a técnica proposta por Mitchel e Amos (2), cêrca de $100 \mathrm{mg}$ de limalha (*), na forma de partículas esféricas, cujos diâmetros variaram de 15 a 70 micra $(* *)$, na linha mediana dorsal de 14 camundongos machos de 60 dias de idade. Os animais foram sacrificados em grupos de 6 , aos 12, 13,14 e 15 meses após a implanta- 
ção. O local da implantação era fàcilmente identificado quer pela coloração da pele, quer radiogràficamente. Os tecidos que circundavam - local de implantação constituiamse no material a ser examinado. Êste material foi preparado e corado pelas técnicas de $\mathrm{H}$. e E., Van Giesen, P.A.S., e ,azul de toluidina para mastócitos.

\section{RESULTADOS}

As esferas de limalha permaneceram, durante os tempos descritos, em contato com tecido conjuntivo (fig. 1 e 2), tecido muscular estriado (fig. 3), tecido gorduroso (figs. 1 e 3) e tecido gorduroso pardo, sem produzir alterações morfológicas significativas.

\section{REFERÊNCIAS BIBLIOGRÁFICAS}

1. KORAN, A. \& ASGARD, K.A. Comparison of dental amalgams made from a spherical alloy and from a comminuted alloy. Journal of American Dental Association, Chicago, 75:912-17, 1967.

2. MITCHEL, D.F. \& AMES, E.R. Reaction of connective tissues of rats to implanted dental materials. International Association for Dental Research, 59-60, 1957.

3. MITCHEL, D.F. et alii. Determinig the tumorigenity of dental materials. Journal of Dental Research, Chicago, 39:1023-1028, 1960.

\section{SYNOPSIS}

Introduction os spherical alloys particles (size range from 15 to 70 micra) in the back at the level of the first thoracic vertebra of 24 male rats, 60 døys old, for a period of time of 12, 13.14 and, 15 months, shows no alteration in the connective tissue, striate muscle, fatty tissue, brown fatty tissue, nerve fibres and hair follicle.

(*) A limalha foi gentilmente cedida pelo Professor Léo W. Süffert.

${ }^{(* *)}$ As medições foram realizadas pelo Professor Manoel Frajndlich. 


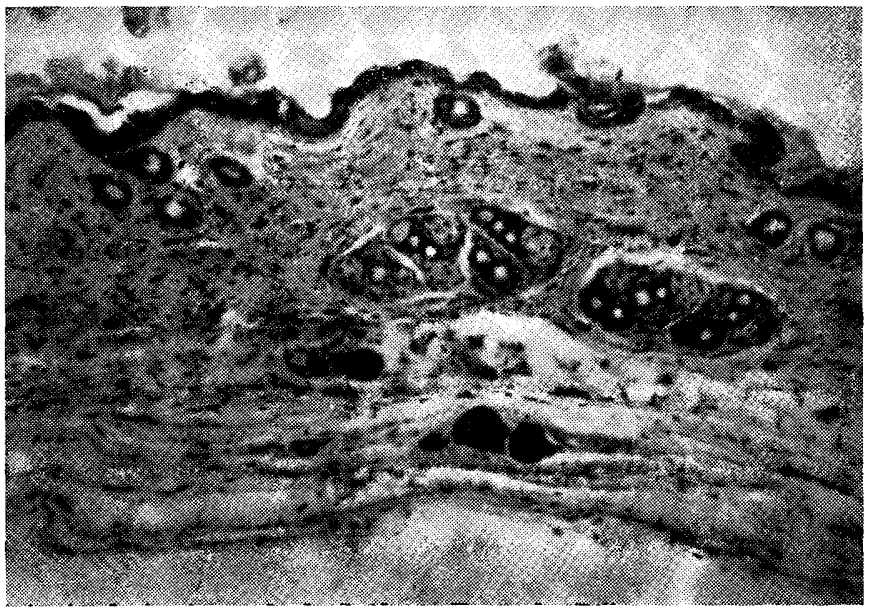

Fig. 1

Esfieras no tecido conjuntivo. Ausência de reação. Tempo: 15 meses.

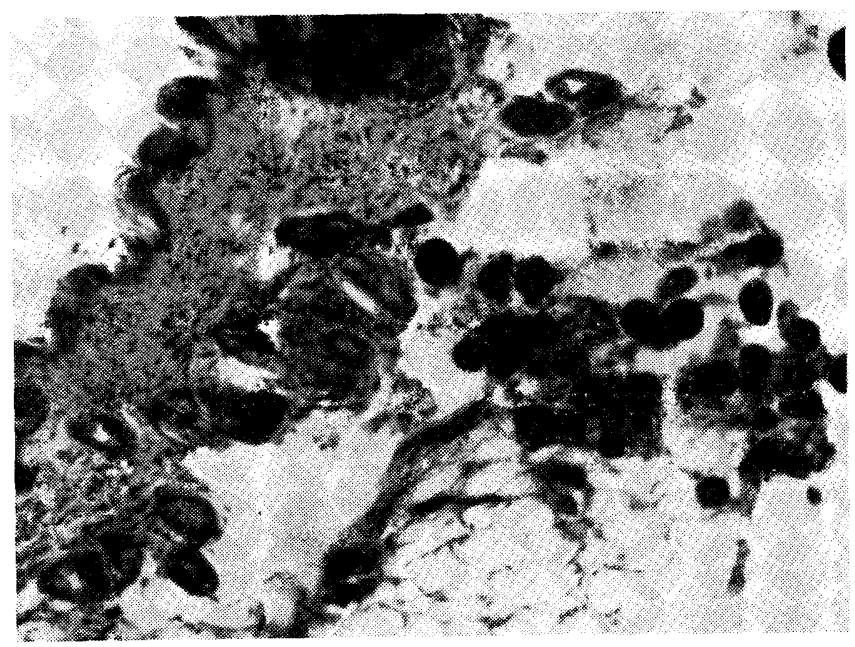

Fig. 2

Esferas no tecido conjuntivo, junto a folículo piloso e tecido gorduroso. Ausência de reação.

Tempo: 15 meses.

R. Fac. Odont. P. A.

10/11: $9 \cdot 12,1968 / 1969$ 


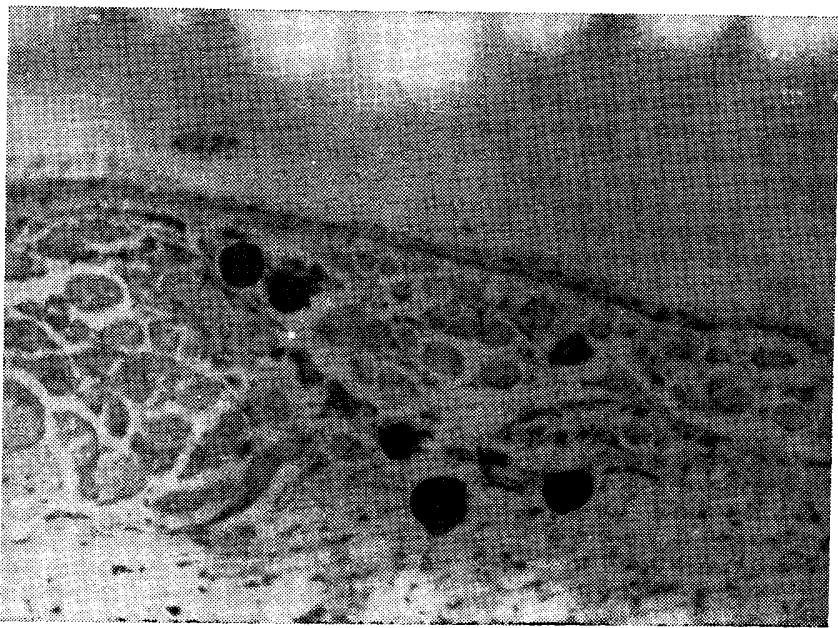

Fig. 3

Esferas no tecido muscular estriado e gorduroso. Ausência de reação.

Tempo: 15 meses. 